\title{
Quality improvement of common carp (Cyprinus carpio L.) meat fortified with n-3 PUFA
}

\author{
M. Sobczak ${ }^{\mathrm{a}}$, R. Panicz ${ }^{\mathrm{a}}$, P. Eljasik ${ }^{\mathrm{a}, *}$, J. Sadowski $^{\mathrm{b}}$, A. Tórz ${ }^{\mathrm{b}}$, J. Żochowska-Kujawska $^{\mathrm{a}}$, \\ V. Barbosa ${ }^{c}$, V. Domingues ${ }^{\mathrm{d}}$, A. Marques ${ }^{\mathrm{c}}$, J. Dias $^{\mathrm{e}}$ \\ ${ }^{a}$ Department of Meat Science, Faculty of Food Science and Fisheries, West Pomeranian University of Technology, Szczecin, Poland \\ ${ }^{\mathrm{b}}$ Department of Aquatic Bioengineering and Aquaculture, Faculty of Food Science and Fisheries, West Pomeranian University of Technology, Szczecin, Poland \\ ${ }^{\mathrm{c}}$ Divisão de Aquacultura, Valorização e Bioprospecção, Instituto Português do Mar e da Atmosfera, IP, Lisboa, Portugal \\ ${ }^{\mathrm{d}}$ Group of Reactions and Chemical Analyses, Department of Chemical Engineering, Superior Institute of Engineering of Porto, Rua Dr. António Bernardino de Almeida, 431, \\ 4200-072, Porto, Portugal \\ ${ }^{\mathrm{e}}$ Sparos Lda, Área Empresarial de Marim, Lote C, 8700-221, Olhão, Portugal
}

\section{A R T I C L E I N F O}

\section{Keywords:}

Fish feeding

Schizchytrium sp.

Fillet

Nutritional value

Sensory properties

\begin{abstract}
A B S T R A C T
The effect of carp feeding with n-3 PUFA-enriched feed (Schizochytrium sp. meal or salmon oil) on nutritional quality indicators (proximal composition, fatty acid profile of fat) and culinary quality (color parameters, texture, sensory properties) was evaluated. Highly significant effects of carp nutrition on chemical composition and fat characteristics, $L^{*}$ and $a^{*}$ color parameters, muscle fiber size, endomysium thickness, moisture and taste of fillets were determined. Fillets obtained from carps fed with the experimental feed contained less protein and more crude fat and had larger muscle fibers, but scored more highly in the sensory evaluation of moisture and fishy taste. In the fat of carp fed the enriched feed, a greater share of total PUFA, n-3 PUFA, total EPA and DHA, n-3/n-6 ratio, and a smaller share of total MUFA were observed compared with control fish. However, no effect of nutrition on the texture of carp fillets, assessed either instrumentally or using sensory methods, was found. The use of Schizchytrium sp. meal as a source of EPA and DHA gave much better results than salmon oil, as it allowed a higher content of these valuable fatty acids to be achieved, without compromising quality.
\end{abstract}

\section{Introduction}

Fish in the human diet are a source of easily digestible proteins, nutritious fats and fat-soluble vitamins (D, A), as well as micro- and macro-elements (e.g. I, Ca, Se). Fish lipids are particularly valuable because of their favorable fatty acid profile, including the high proportion of long-chain fatty acids, especially n-3 and n-6 EFA (essential fatty acid). Fatty acids EPA (20:5, n-3, eicosapentaenoic acid) and DHA (22:6, n-3, docosahexaenoic acid) have a very positive effect on health and are recommended for the reduction of cardiovascular disease (Calder, 2006; Calder and Yaqoob, 2009, 2010). Despite the high nutritional value of fish, consumption is far below levels recommended by nutritionists. The World Health Organization, together with Food and Agriculture Organization (WHO/FAO, 2003), recommend regular consumption of fish (1-2 times a week), including one portion of oily fish providing 200-500 mg of EPA and DHA. Despite these recommendations, most consumers globally eat fish less than once a week
(Skibniewska et al., 2009; Pieniak et al., 2010; Dymkowska-Malesa et al., 2014; Maciel et al., 2019). One of the reasons for the lower popularity of fish (compared with meat) are their specific sensory features (i.e. smell, taste). Proteins and lipids (and post-mortem transformation of these compounds) are responsible for palatability, and fish lipids are particularly susceptible to oxidative changes due to their high content of unsaturated FA (fatty acids) which contribute strongly to the deterioration of the sensory quality and taste (Fauconneau et al., 1995).

Carp (Cyprinus carpio L.) is the main freshwater fish species bred in many European, Asian and Latin American countries. Carp contains $11.8-18 \%$ protein and $6.8-12.4 \%$ fat, the latter of which consists of 24.3-30.0\% SFA (saturated fatty acids) and 70.0-75.7\% unsaturated fatty acids, including $48.6 \%$ MUFA (monounsaturated fatty acids) and $21.5 \%$ PUFA (polyunsaturated fatty acids). Carp lipids are composed of $1.3-6.7 \%$ of n-3 FA, including $\Sigma \mathrm{EPA}+$ DHA constituting $0.5-4.3 \%$ of FA, and 1.3-14.8\% n-6 FA (Grela et al., 2010; Woźniak et al., 2013; Ljubojevic et al., 2013). The variable nutrient content of carp is due to

\footnotetext{
* Corresponding author. Department of Meat Science, Faculty of Food Science and Fisheries, West Pomeranian University of Technology, Kazimierza Królewicza 4, 71-550, Szczecin, Poland.

E-mail address: peljasik@zut.edu.pl (P. Eljasik).
} 


\author{
Abbreviations \\ CSA cross-sectional area \\ DHA docosahexaenoic acid (22:6n-3) \\ EPA eicosapentaenoic acid (20:5n-3) \\ FA fatty acid \\ HUFA highly unsaturated fatty acid
}

MUFA monounsaturated fatty acid

n-3 PUFA total omega-3 polyunsaturated fatty acid

n-6 PUFA total omega- 6 polyunsaturated fatty acid

n-9 PUFA total omega-9 polyunsaturated fatty acid

PUFA polyunsaturated fatty acids

SFA saturated fatty acids

WI whiteness index different living conditions and food sources. Therefore, these factors can be used by breeders to alter the nutritional make-up of carp. The nutritional quality of this species can be improved for human consumption by selecting the right feed composition and enrichment with nutrients, particularly those present in smaller amounts (e.g., EPA and DHA). Indeed, breeding experiments have shown that feeding common carp with mixed feed affects proximate composition (Manjappa et al., 2002; Aprodu et al., 2012) and fatty acid profile, including the EPA and DHA contents (Buchtová et al., 2007; Aprodu et al., 2012). Increased EPA and DHA in carp can be achieved by the introduction of fats into feed from different natural sources, including microalgae (e.g. Schizochytium sp.), fish or vegetables oils. The use of microalgal oils from Schizochytrium sp. for fortification is considered safe, as no reports have revealed potential exposure to toxic chemicals or pathogens (Ryan et al., 2010). Microalgal oil is recognized by the Food and Drug Administration of the United States of America (FDA) as permitted for use in infant formulae, and food and dietary supplements (Fedorova-Dahms et al., 2011). However, there is a lack of information about the effects of increased EPA and DHA in carp on culinary quality.

The aim of this study was to assess the quality of carp fed with feed enriched with the EPA + DHA fatty acids from natural sources and to check whether using such blends would increase the nutritional value of carp fillets without compromising their structure, texture and sensory quality parameters.

\section{Materials and methods}

\subsection{Experimental diets}

The trial comprised four experimental diets (Table 1). A control diet, mimicking a commercial feed formulation for common carp, with moderate levels of fishmeal (5\%) and high levels of plant raw materials and vegetable oils (rapeseed and soybean) as sole fat sources. In comparison, in the three test diets (CB1, CB2 and CB3), half of the fishmeal was replaced with a blend of microalgae (Spirulina sp., Chlorella sp.), macroalgae (Laminaria digitata) and salinized yeast. Additionally, fat fractions were supplied via blends of vegetable oils, and a DHA-rich alga (Schizochytrium sp.) at $3.125 \%$ (diet CB1) and $1.563 \%$ (diet CB2), and salmon oil (diet CB3), respectively. All feeds were produced by extrusion at Sparos Lda facilities (Olhão, Portugal).

\subsection{Fish, rearing and housing facilities}

This study was conducted at the Division of Aquaculture, Faculty of Food Science and Fisheries, West Pomeranian University of Technology, Szczecin, Poland. Common carp (Cyprinus carpio L.) was obtained from the Experimental Fisheries Station in Nowe Czarnowo $\left(53^{\circ} 12^{\prime} 36^{\prime \prime} \mathrm{N}\right.$, $\left.14^{\circ} 27^{\prime} 48^{\prime \prime} \mathrm{E}\right)$. The fish were housed in floating cages, placed in the cooling water discharge canal of the Dolna Odra power plant, and fed with a commercial diet (Aller Classic, containing 30\% protein and $7 \%$ fat; Aller Aqua Poland, Czarna Dąbrówka, Poland) prior to the start of the experiment. In total, 12 cuboid cages of $3 \mathrm{~m}^{3}$ placed in four rows of three were used (three cages per feed). Each cage was stocked with 100 fish with an average starting weight of $296 \pm 10 \mathrm{~g}$. The feeding trial was conducted for 100 days during which fish were hand-fed with the feed blends (control and CB1-3, Table 1) in equal portions at 9:00 and
15:00 h. At the end of the last day of the trial, $n=10$ fish from each cage were slaughtered, following commercial practices, and filleted. Filleting was performed by one individual. All fish samples were stored at $4{ }^{\circ} \mathrm{C}$ until analysis.

\subsection{Color measurement}

Fillet color was assessed using an NR 20XE Precision Colorimeter (Shenzhen 3NH Technology Co., Ltd., Shenzhen, China) with $\phi=20 \mathrm{~mm}$ extended aperture. L* (lightness), a* (redness), b* (yellowness) were obtained automatically after a light shot was discharged perpendicularly to the inner surface of the fillet. Measurements were done in triplicate. The whiteness index (WI $=100-[(100-$ $\left.\left.\mathrm{L})^{2}+\mathrm{a}^{2}+\mathrm{b}^{2}\right]^{0.5}\right)$ and chromaticity $\left(\mathrm{C}=\left(\mathrm{a}^{2}+\mathrm{b}^{2}\right)^{0.5}\right)$ were calculated using the obtained values.

\subsection{Chemical analysis}

The chemical composition of minced fillets was determined according to AOAC (2012) methods. Moisture was obtained after drying samples in an oven at $105{ }^{\circ} \mathrm{C}$ for $24 \mathrm{~h}$, while ash content was determined after incineration at $550{ }^{\circ} \mathrm{C}$ for $6 \mathrm{~h}$. Crude protein was measured by determining nitrogen content ( $\mathrm{N} \times 6.25)$, according to the Kjeldahl method, using a Tecator Kjeltec 2100 distillation unit (FOSS Analytical Co., Ltd., Jiangsu, China), and crude lipid was determined gravimetrically, after Soxhlet lipid extraction on a Tecator Soxtec System HT 1043 (FOSS Analytical Co., Ltd., Jiangsu, China). Fatty acid profiles were quantified using gas chromatography (GC) with a flame ionization detector (FID) by Polcargo (Szczecin) in accordance with PNEN ISO 12966-1:2015-01. Briefly, fatty acids were determined as fatty acid methyl esters (FAME), and individual FAME were identified by comparing their retention times with those of pure standards. Analyses were carried out in triplicate on an Agilent $6890 \mathrm{~N}$ Network Gas Chromatograph (Agilent Technologies; Palo Alto, CA) equipped with a 7683 automatic liquid sampler and flame ionization detectors.

\subsection{Structure}

From each fillet, $5 \times 5 \times 10 \mathrm{~mm}$ samples were cut, fixed for $12 \mathrm{~h}$ in Sannomiya, dehydrated using alcohol saturated in benzene followed by benzene:paraffin, embedded in paraffin blocks, and sectioned using a Rotary Microtome MPS-2 (Opta-Tech) into slices of $10 \pm 1 \mu \mathrm{m}$. The sections were mounted on clear glass slides, contrast-stained with hematoxylin and eosin, and sealed with Canada balsam (Burck, 1975). MultiScanBase v.13.01 (Computer Scanning System Ltd., Warszawa, PL). image analysis software was used to record muscle fiber parameters, i.e. cross-sectional area (CSA) and average diameter, as well as thickness of connective tissue surrounding every muscle fiber (endomysium). Three slides were prepared from each excised sample and analyzed. Approximately 150 muscle fibers and up to 100 endomysia were assessed on each slide.

\subsection{Thawing and cooking losses}

Right fillets were weighed, wrapped in a plastic wrap, and frozen at $-18 \pm 1{ }^{\circ} \mathrm{C}$. After 2 months in storage, the fillets were thawed at room 
Table 1

Composition of experimental feeds.

\begin{tabular}{|c|c|c|c|c|}
\hline Ingredients, \% & Control & CB1 & CB2 & CB3 \\
\hline Fishmeal $60^{\mathrm{a}}$ & 5.000 & 2.500 & 2.500 & 2.500 \\
\hline Porcine blood meal ${ }^{\mathrm{b}}$ & 2.000 & 2.000 & 2.000 & 2.000 \\
\hline Algae meal (Spirulina sp.) ${ }^{c}$ & & 1.000 & 1.000 & 1.000 \\
\hline Algae meal (Chlorella sp.) ${ }^{d}$ & & 1.000 & 1.000 & 1.000 \\
\hline Algae meal (Schizochytrium sp.) & & 3.125 & 1.563 & \\
\hline Soy protein concentrate ${ }^{f}$ & 2.500 & 2.500 & 2.500 & 2.500 \\
\hline Corn gluten meal ${ }^{g}$ & 4.000 & 4.000 & 4.000 & 4.000 \\
\hline Soybean meal $44^{h}$ & 25.000 & 25.000 & 25.000 & 25.000 \\
\hline Rapeseed meal ${ }^{\mathrm{i}}$ & 7.000 & 7.000 & 7.000 & 7.000 \\
\hline Sunflower meal ${ }^{\mathrm{j}}$ & 12.500 & 12.500 & 12.500 & 12.500 \\
\hline Wheat meal ${ }^{\mathrm{k}}$ & 22.500 & 21.224 & 21.786 & 22.349 \\
\hline Wheat bran ${ }^{1}$ & 5.000 & 5.000 & 5.000 & 5.000 \\
\hline Corn meal ${ }^{\mathrm{m}}$ & 2.500 & 2.500 & 2.500 & 2.500 \\
\hline Salmon oil ${ }^{\mathrm{n}}$ & & & & 2.100 \\
\hline Soybean oil ${ }^{\circ}$ & 3.000 & & & 2.000 \\
\hline Rapeseed oil ${ }^{\circ}$ & 3.000 & 4.100 & 5.100 & 2.000 \\
\hline Vitamins and minerals premix ${ }^{p}$ & 1.000 & 1.000 & 1.000 & 1.000 \\
\hline Betaine $\mathrm{HCl}^{\mathrm{q}}$ & 0.100 & 0.100 & 0.100 & 0.100 \\
\hline Binder ${ }^{r}$ & 1.000 & 1.000 & 1.000 & 1.000 \\
\hline Macroalgae meal (Laminaria digitata) ${ }^{\mathrm{s}}$ & & 0.541 & 0.541 & 0.541 \\
\hline Antioxidant ${ }^{\mathrm{t}}$ & 0.200 & 0.200 & 0.200 & 0.200 \\
\hline Sodium propionate ${ }^{\mathrm{u}}$ & 0.100 & 0.100 & 0.100 & 0.100 \\
\hline Sodium phosphate ${ }^{v}$ & 2.100 & 2.100 & 2.100 & 2.100 \\
\hline Selenised yeast ${ }^{\mathrm{w}}$ & & 0.010 & 0.010 & 0.010 \\
\hline L-Lysine ${ }^{\mathrm{x}}$ & 0.700 & 0.700 & 0.700 & 0.700 \\
\hline L-Tryptophan ${ }^{y}$ & 0.200 & 0.200 & 0.200 & 0.200 \\
\hline DL-Methionine ${ }^{z}$ & 0.600 & 0.600 & 0.600 & 0.600 \\
\hline
\end{tabular}

a CONRESA 60: $61.2 \%$ crude protein (CP), 8.4\% crude fat (CF), Conserveros Reunidos S.A., Spain.

b Porcine blood meal: $89 \% \mathrm{CP}, 1 \% \mathrm{CF}$, SONAC BV, The Netherlands.

c Spirulina meal: $72 \% \mathrm{CP}, 1 \% \mathrm{CF}$, Willows Ingredients Ltd, Ireland.

d Chlorella meal: 62\% CP, 9\% CF, ALLMICROALGAE, Portugal.

e ALL-G RICH (Schizochytrium), Alltech Portugal.

f Soycomil P: $63 \%$ CP, 0.8\% CF, ADM, The Netherlands.

g Corn gluten meal: 61\% CP, 6\% CF, COPAM, Portugal.

h Solvent extracted soybean meal: $43.8 \%$ CP, 3.3\% CF, CARGILL, Spain.

${ }^{\mathrm{i}}$ Defatted rapeseed meal: $32.7 \% \mathrm{CP}, 4.1 \% \mathrm{CF}$, Ribeiro \& Sousa Lda, Portugal.

j Defatted sunflower meal: $29.1 \%$ CP, $1.8 \%$ CF, Ribeiro \& Sousa Lda, Portugal.

k Wheat meal: $10.2 \% \mathrm{CP}, 1.2 \% \mathrm{CF}$, Casa Lanchinha, Portugal.

1 Wheat bran: $14.9 \%$ CP, 4.0\% CF, Cerealis Moagens S.A., Portugal.

${ }^{m}$ Corn meal: $8 \%$ CP, $3.7 \%$ CF, Ribeiro \& Sousa Lda, Portugal.

n Sopropêche, France.

- Lamotte Oils GmbH, Germany.

p INVIVONSA Portugal SA, Portugal: Vitamins (IU or $\mathrm{mg} / \mathrm{kg}$ diet): DL-alpha tocopherol acetate, $100 \mathrm{mg}$; sodium menadione bisulphate, $25 \mathrm{mg}$; retinyl acetate, $20000 \mathrm{IU}$; DL-cholecalciferol, $2000 \mathrm{IU}$; thiamin, $30 \mathrm{mg}$; riboflavin, $30 \mathrm{mg}$; pyridoxine, $20 \mathrm{mg}$; cyanocobalamin, $0.1 \mathrm{mg}$; nicotinic acid, $200 \mathrm{mg}$; folic acid, $15 \mathrm{mg}$; ascorbic acid, $500 \mathrm{mg}$; inositol, $500 \mathrm{mg}$; biotin, $3 \mathrm{mg}$; calcium panthotenate, $100 \mathrm{mg}$; choline chloride, $1000 \mathrm{mg}$, betaine, $500 \mathrm{mg}$. Minerals ( $\mathrm{g}$ or $\mathrm{mg} / \mathrm{kg}$ diet): copper sulphate, $9 \mathrm{mg}$; ferric sulphate, $6 \mathrm{mg}$; potassium iodide, $0.5 \mathrm{mg}$; manganese oxide, $9.6 \mathrm{mg}$; sodium selenite, $0.01 \mathrm{mg}$; zinc sulphate, $7.5 \mathrm{mg}$; sodium chloride, $400 \mathrm{mg}$; excipient wheat middling's.

q ORFFA, The Netherlands.

$r$ CELATOM FP1SL (diatomite), Angelo Coimbra S.A., Portugal.

s Dry Laminaria digitata: 5.4\% CP, 0.5\% CF, $3700 \mathrm{mg}$ iodine/kg, Agrimer, France.

t VERDILOX, Kemin Europe NV, Belgium.

u PREMIX LDA., Portugal.

$\checkmark$ Vadequimica, Spain.

w ALKOSEL R397: 2200 mg selenium/kg, Lallemand, France.

x L-Lysine HCl 99\%: Ajinomoto Eurolysine SAS, France.

y TrypAMINO 98\%, Evonik Nutrition \& Care GmbH, Germany.

${ }^{\mathrm{z}}$ DL-METHIONINE FOR AQUACULTURE 99\%, EVONIK Nutrition \& Care GmbH, Germany.

temperature and weighed again to calculate thawing losses. Subsequently, the fillets were steamed until their internal temperature reached $68 \pm 1{ }^{\circ} \mathrm{C}$ in the thickest portion of the fillet, before being cooled to $5 \pm 1{ }^{\circ} \mathrm{C}$. After chilling, the samples were weighed to calculate cooking losses.

\subsection{Texture profile analysis}

The texture of the steamed fillets was measured with a TA.XT Plus Texture Analyser (Stable Micro Systems, Godalming, UK) in a double compression TPA test (Bourne, 1982). Briefly, in the TPA test, a 9.6-mm shaft was driven into the sample twice to a depth of $80 \%$ of the original height, and parameters such as hardness (N), cohesiveness (-), springiness $(\mathrm{cm})$ and chewiness $(\mathrm{N} \times \mathrm{cm})$ were measured. Crosshead speed was $50 \mathrm{~mm} / \mathrm{min}$. TPA was run a minimum of five times for each fillet.

\subsection{Sensory analysis}

Sensory evaluation of the steamed fillets was conducted by a trained team composed of four members (PN-ISO 11036:1999). Color evenness, texture characteristics (tenderness, chewiness, moisture, juiciness, fattiness), as well as intensity of odor and taste descriptors were evaluated. The intensity of these features was rated using a 5-point scale, where 1 point corresponded to the lowest and 5 points the highest intensity.

\subsection{Statistical analysis}

Data were analyzed using STATISTICA for Windows (version 13.1) and subjected to two-way analysis of variance (ANOVA) and Tukey's test to compare sample means. Differences were considered as statistically significant at $\mathrm{P} \leq 0.05$.

\section{Results}

\subsection{Proximate composition and fat characteristics of fillets}

A highly significant $(\mathrm{P} \leq 0.01$ ) effect of carp feeding on the chemical composition (Table 2) and fat characteristics (Table 3) of fillets was achieved. Fillets from fish fed fortified feeds were characterized by a lower protein content and greater amounts of dry matter and fat, compared with the controls. No significant differences in ash content were found. The percentage of total MUFA was significantly $(\mathrm{P} \leq 0.01$ ) lower and total PUFA significantly $(P \leq 0.01$ ) higher in fillets from fish fed fortified diets compared with fillets from fish on the control diet. The largest differences were between the control and the CB3-fed carp (7 and 17\%, respectively). Total n-3 PUFA contents in carp fed fortified feeds were 1.7-2.5 times higher than in fat from the control fish. Differences in the relative proportions of EPA + DHA between the fortified-feed and the control carp fillets were even greater; fat from the fish fed CB1-CB3 contained 2.1-3.9 times more of these valuable fatty acids. Fat from the CB3 group contained similar amounts of total $n-6$ and total n-9 PUFA as the control samples. In contrast, fat from the CB1 and $\mathrm{CB} 2$ groups contained significantly $(\mathrm{P} \leq 0.01)$ less total n-9 PUFAs. The lowest total n-6 PUFA content was recorded in the CB1-fed fish, whereas the highest was in the fish from the CB2 groups. The $n-3 / n-6$ indices for fortified samples were significantly $(P \leq 0.01)$ higher compared with the controls. The largest differences were for CB1 (153\%), and the smallest for CB3 (60\%). However, no significant $(\mathrm{P}>0.05)$ differences were found in the contents of SFA or the PUFA:SFA ratio, although the fat from the fish fed with the fortified feeds (CB1-CB3) showed a trend for less SFA and had higher PUFA:SFA ratios.

\subsection{Color, thawing and cooking loss of fillets}

Data presented in Table 4 show that the types of feed used had a significant $(\mathrm{P} \leq 0.05)$ effect on the $\mathrm{L}^{*}, \mathrm{a}^{*}$ and WI parameters, while 
Table 2

Effect of fish feeding on proximate composition of carp fillets. Values are expressed as mean \pm standard deviation (SD).

\begin{tabular}{|c|c|c|c|c|c|}
\hline Component (\% of wet weight) & Control & CB1 & CB2 & CB3 & Significance of influence \\
\hline Crude protein & $16.37 \mathrm{a} \pm 0.020$ & $16.19 b \pm 0.040$ & $15.99 c \pm 0.060$ & $15.98 \mathrm{~cd} \pm 0.030$ & $* *$ \\
\hline Dry matter & $20.74 a \pm 0.355$ & $21.58 b \pm 0.240$ & $21.06 \mathrm{ab} \pm 0.175$ & $22.28 c \pm 0.145$ & $* *$ \\
\hline Crude fat & $2.98 \mathrm{a} \pm 0.355$ & $3.68 \mathrm{ab} \pm 0.515$ & $3.07 \mathrm{a} \pm 0.125$ & $4.51 b \pm 0.160$ & $* *$ \\
\hline Ash & $1.04 \pm 0.025$ & $1.08 \pm 0.031$ & $1.01 \pm 0.042$ & $1.05 \pm 0.018$ & n.s. \\
\hline
\end{tabular}

$\mathrm{ab}$ - values in rows with different index differ significantly ( $\mathrm{p} \leq 0.05$ ).

Significance of influence: n.s. - non significant, * $\mathrm{p} \leq 0.05 ; * * \mathrm{p} \leq 0.01$.

dietary composition did not affect $(\mathrm{P}>0.05)$ the $\mathrm{b}^{*}$ and $\mathrm{c}$ color parameters. Fillets from the CB3-fed fish were characterized by a significantly lighter color $\left(L^{*}\right)$ than the control carp, which was not significantly different from the CB1 and CB2 groups. The reddest shade was found in fillets from the fish in the CB3 and CB1 groups; the parameter a* for these fish was significantly higher (56.8-58.5\%) than in the control samples which were the least red in color. Fillets from the CB2-fed fish did not differ significantly for a* from the controls or the $\mathrm{CB} 3$ groups samples. Fish nutrition also had a significant $(\mathrm{P} \leq 0.01)$ effect on weight losses during thawing: the largest thawing loss was observed in the CB3 group and was $82-117 \%$ greater than in other the groups which did not differ significantly from one another. There was no effect of carp nutrition on weight losses after heat treatment.

\subsection{Muscle structure}

Carp feeding had a significant effect on the size of muscle fiber cross-sectional area (CSA, $\mathrm{P} \leq 0.01)$ and diameter $(\mathrm{P} \leq 0.05)$, as well as thickness of the connective tissue surrounding muscle fibers-endomysium ( $\mathrm{P} \leq 0.01$ ) (Table 5). Similarly sized fibers were found in fillet muscles from CB1, which had the thinnest endomysium. CB2 muscles had the largest muscle fibers (approx. 25.6\% larger CSA than the controls) and the thickest endomysium (approx. 11.5\% thicker than CB1).

\subsection{Texture of fillets}

No significant $(P>0.05)$ effects of fish nutrition on the TPA test parameters were found in this study (Table 6). However, it should be noted that carp fillets receiving fortified feeds (CB1, CB2, CB3) demonstrated trends suggesting greater hardness and chewiness and lower springiness than the controls.

\subsection{Sensory assessment of fillets}

Feeds with different nutritional compositions significantly ( $\mathrm{P} \leq 0.05)$ affected moisture and taste (Table 7). Fillets from the CB3fed fish had the least moisture perception, whereas the control fillets had the lowest intensity of fishy taste and odor, compared with the other groups. There was no significant $(P>0.05)$ effect of fish nutrition on other sensory characteristics. However, the control fillets were rated as having the least fatty taste, lower fishy odor and taste, and higher intensity for boiled meat odor and taste compared to fillets from the fish fed with fortified feeds. The least tender, chewy and juicy were fillets (from the CB3-fed fish) characterized by a less intense boiled meat odor and taste. Fillets from carp fed with the fortified feeds received higher scores for fishy odor and taste compared with the control.

\section{Discussion}

Feeding carp with fortified feeds significantly affected the proximate chemical compositions and fat profiles of their fillets. The highest protein content in the control fillets was probably due to the feed containing twice as much fishmeal as the fortified feeds (CB1-CB3). Mazurkiewicz et al. (2011) did not show significant differences in the crude protein content of carp fed with different proportions of meal (fish, soybean, wheat) and rapeseed oil. Yet, together with an increase in meals and a decrease in rapeseed oil, these authors observed an increase in crude fat content. In our study, the highest fat contents were observed in fillets from the CB3-fed fish. CB3 contained the most fat and was the only one to contain salmon oil and not Schizochytrium sp. meal. Fillets from the CB1- and CB2-fed fish were characterized by high fat contents, greater than controls, despite the feed containing lower amounts of fat. In this case, the additional source of fat in the feed was algal meal from Schizochytrium sp., which contains $45.3 \mathrm{~g} / 100 \mathrm{~g}$ of crude fat (Hadley et al., 2017).

The nutritional value of fish, in addition to their chemical composition, is determined by the quality of fats (Ljubojević et al., 2012). Feeding with Schizochytrum sp. algae and salmon oil significantly altered the fatty acid profile not only of the diet but also of the carp muscle fat. According to Fauconneau et al. (1995), supply of high PUFA diets leads directly to a higher PUFA incorporation in fish muscle. Indeed, feed containing fish oil favors accumulation of HUFA (highly unsaturated fatty acids, with $>4$ double bonds), especially EPA and

Table 3

Effect of fish feeding on selected fat characteristics of carp fillets. Values are expressed as mean \pm standard deviation (SD).

\begin{tabular}{|c|c|c|c|c|c|}
\hline & Control & CB1 & CB2 & CB3 & Significance of influence \\
\hline Total SFA (\% of FA) & $22.5 \pm 1.79$ & $21.9 \pm 2.14$ & $21.8 \pm 2.08$ & $21.8 \pm 1.97$ & n.s. \\
\hline Total MUFA ( $\%$ of FA) & $54.0 \mathrm{a} \pm 0.020$ & $52.0 \mathrm{~b} \pm 0.215$ & $50.2 c \pm 0.845$ & $52.7 \mathrm{bd} \pm 0.055$ & $* *$ \\
\hline Total PUFA (\% of FA) & $22.1 \mathrm{a} \pm 0.040$ & $24.1 b \pm 0.220$ & $25.9 c \pm 0.630$ & $23.8 \mathrm{bd} \pm 0.010$ & $* *$ \\
\hline PUFA:SFA & $0.99 \pm 0.075$ & $1.11 \pm 0.103$ & $1.19 \pm 0.110$ & $1.10 \pm 0.094$ & n.s. \\
\hline Total n-3 PUFA ( $\%$ of FA) & $2.68 \mathrm{a} \pm 0.020$ & $6.48 b \pm 0.065$ & $5.96 c \pm 0.235$ & $4.49 \mathrm{~d} \pm 0.025$ & $* *$ \\
\hline C20:5n3 (EPA), (\% of FA) & $0.17 \mathrm{a} \pm 0.001$ & $0.84 \mathrm{~b} \pm 0.001$ & $0.81 b \pm 0.025$ & $0.50 c \pm 0.001$ & $* *$ \\
\hline C22:6n3 (DHA), (\% of FA) & $0.91 \mathrm{a} \pm 0.015$ & $3.33 b \pm 0.070$ & $2.97 b \pm 0.190$ & $1.80 c \pm 0.030$ & $* *$ \\
\hline $\mathrm{EPA}+\mathrm{DHA}(\%$ of FA) & $1.08 \mathrm{a} \pm 0.001$ & $4.17 b \pm 0.070$ & $3.78 c \pm 0.215$ & $2.30 \mathrm{~d} \pm 0,030$ & $* *$ \\
\hline Total n-6 PUFA ( $\%$ of FA) & $18.45 \mathrm{a} \pm 0.025$ & $16.90 \mathrm{~b} \pm 0.140$ & $19.10 \mathrm{c} \pm 0.360$ & $18.57 \mathrm{a} \pm 0.015$ & $* *$ \\
\hline Total n-9 PUFA ( $\%$ of FA) & $43.81 \mathrm{a} \pm 0.020$ & $40.53 b \pm 0.230$ & $39.20 c \pm 0.850$ & $43.16 \mathrm{a} \pm 0.070$ & $* *$ \\
\hline$n-3 / n-6$ & $0.15 \mathrm{a} \pm 0.001$ & $0.38 b \pm 0.001$ & $0.31 c \pm 0.006$ & $0.24 \mathrm{~d} \pm 0.002$ & $* *$ \\
\hline
\end{tabular}

ab - values in rows with different index differ significantly ( $\mathrm{p} \leq 0.05$ ).

Significance of influence: n.s. - non significant, * $\mathrm{p} \leq 0.05 ;{ }^{* *} \mathrm{p} \leq 0.01$.

Explanations: SFA-saturated fatty acids, MUFA - monounsaturated fatty acids, PUFA - polyunsaturated fatty acids, FA - total fatty acids. 
Table 4

Effect of fish feeding on colour parameters, thawing and cooking loss of carp fillets. Values are expressed as mean \pm standard deviation (SD).

\begin{tabular}{|c|c|c|c|c|c|}
\hline & Control & $\mathrm{CB} 1$ & CB2 & CB3 & Significance of influence \\
\hline$L^{*}$ & $55.8 \mathrm{a} \pm 1.42$ & $53.7 \mathrm{ab} \pm 0.51$ & $55.1 \mathrm{ab} \pm 1.34$ & $52.2 b \pm 1.08$ & $*$ \\
\hline$a^{*}$ & $2.29 \mathrm{a} \pm 0.198$ & $3.59 b \pm 0.294$ & $2.75 \mathrm{ac} \pm 0.503$ & $3.63 b c \pm 0.84$ & * \\
\hline$b^{*}$ & $11.56 \pm 0.610$ & $12.22 \pm 0.396$ & $12.03 \pm 0.394$ & $12.08 \pm 0.298$ & n.s. \\
\hline WI & $54.2 \mathrm{a} \pm 1.55$ & $52.0 \mathrm{ab} \pm 0,57$ & $53.4 \mathrm{ab} \pm 1.41$ & $50.6 b \pm 0.96$ & $*$ \\
\hline c & $11.78 \pm 0.598$ & $12.74 \pm 0.365$ & $12.34 \pm 0.470$ & $12.64 \pm 0.324$ & n.s. \\
\hline Thawing loss (\%) & $2.02 \mathrm{a} \pm 0.087$ & $2.31 \mathrm{a} \pm 0.071$ & $2.41 \mathrm{a} \pm 0.241$ & $4.39 b \pm 1.117$ & $* *$ \\
\hline Cooking loss (\%) & $9.94 \pm 0.800$ & $9.89 \pm 1.412$ & $8.49 \pm 1.854$ & $9.65 \pm 0.886$ & n.s. \\
\hline
\end{tabular}

ab - values in rows with different index differ significantly ( $\mathrm{p} \leq 0.05)$.

Significance of influence: n.s. - non significant, ${ }^{*} \mathrm{p} \leq 0.05 ;{ }^{*} \mathrm{p} \leq 0.01$.

Table 5

Effect of fish feeding on structural elements of carp fillets. Values are expressed as mean \pm standard deviation (SD).

\begin{tabular}{|c|c|c|c|c|c|}
\hline & Control & CB1 & CB2 & CB3 & Significance of influence \\
\hline \multicolumn{6}{|l|}{ Muscle fibre: } \\
\hline $\operatorname{CSA}\left(\mu \mathrm{m}^{2}\right)$ & $3005 \mathrm{a} \pm 382.7$ & $3065 a \pm 133.7$ & $3774 \mathrm{~b} \pm 18.9$ & $3528 \mathrm{ab} \pm 130.1$ & $* *$ \\
\hline Diameter $(\mu \mathrm{m})$ & $59.6 \mathrm{a} \pm 4.47$ & $60.2 \mathrm{ab} \pm 2.16$ & $66.9 b \pm 0.14$ & $64.9 \mathrm{ab} \pm 1.26$ & $*$ \\
\hline \multicolumn{6}{|l|}{ Connective tissue (myocommata) } \\
\hline Endomysium thickness $(\mu \mathrm{m})$ & $2.27 \mathrm{ab} \pm 0.079$ & $2.18 \mathrm{a} \pm 0.069$ & $2.43 \mathrm{~b} \pm 0.106$ & $2.31 \mathrm{ab} \pm 0.082$ & * \\
\hline
\end{tabular}

${ }^{\mathrm{ab}}$ - values in rows with different index differ significantly ( $\left.\mathrm{p} \leq 0.05\right)$.

Significance of influence: $n . s$. - non significant, ${ }^{*} \mathrm{p} \leq 0.05 ;{ }^{*} * \mathrm{p} \leq 0.01$.

Explanations: CSA - cross section area.

Table 6

Effect of fish feeding on TPA test parameters of carp fillets. Values are expressed as mean \pm standard deviation (SD).

\begin{tabular}{|c|c|c|c|c|c|}
\hline Parameter & Control & CB1 & CB2 & CB3 & Significance of influence \\
\hline Hardness $(\mathrm{N})$ & $4.06 \pm 0.775$ & $4.76 \pm 0.820$ & $4.79 \pm 1.956$ & $4.58 \pm 1.046$ & n.s. \\
\hline Cohesiveness (-) & $0.40 \pm 0.024$ & $0.45 \pm 0.054$ & $0.38 \pm 0.077$ & $0.44 \pm 0.025$ & n.s. \\
\hline Springiness $(\mathrm{cm})$ & $0.77 \pm 0.154$ & $0.67 \pm 0.075$ & $0.67 \pm 0.143$ & $0.63 \pm 0.015$ & n.s. \\
\hline Chewiness $(\mathrm{N} \times \mathrm{cm})$ & $1.26 \pm 0.145$ & $1.61 \pm 0.502$ & $1.16 \pm 0.139$ & $1.31 \pm 0.346$ & n.s. \\
\hline
\end{tabular}

ab - values in rows with different index differ significantly ( $\mathrm{p} \leq 0.05$ ).

Significance of influence: n.s. - non significant, ${ }^{*} \mathrm{p} \leq 0.05 ; * * \mathrm{p} \leq 0.01$.

Table 7

Effect of fish feeding on sensory assessment (points) of carp fillets. Values are expressed as mean \pm standard deviation (SD).

\begin{tabular}{|c|c|c|c|c|c|}
\hline Traits (pt.) & Control & $\mathrm{CB} 1$ & $\mathrm{CB} 2$ & СB3 & Significance of influence \\
\hline Color evenness & $3.3 \pm 0.58$ & $3.3 \pm 0.58$ & $3.3 \pm 0.29$ & $2.8 \pm 0.76$ & n.s. \\
\hline \multicolumn{6}{|l|}{ Texture: } \\
\hline tenderness & $2.5 \pm 0.50$ & $2.8 \pm 0.29$ & $2.5 \pm 0.50$ & $2.3 \pm 0.58$ & n.s. \\
\hline chewiness & $2.3 \pm 0.29$ & $2.3 \pm 0.29$ & $2.3 \pm 0.29$ & $2.2 \pm 0.76$ & n.s. \\
\hline moisture & $2.0 \mathrm{ab} \pm 0.00$ & $2.5 a \pm 0.50$ & $2.0 \mathrm{ab} \pm 0.00$ & $1.7 \mathrm{~b} \pm 0.29$ & $*$ \\
\hline juiciness & $2.3 \pm 0.29$ & $2.5 \pm 0.50$ & $2.3 \pm 0.29$ & $2.0 \pm 0.50$ & n.s. \\
\hline fattiness & $2.0 \pm 0.58$ & $2.7 \pm 0.58$ & $2.3 \pm 0.58$ & $2.3 \pm 0.50$ & n.s. \\
\hline \multicolumn{6}{|l|}{ Odor: } \\
\hline boiled meat & $2.3 \pm 0.58$ & $2.2 \pm 0.29$ & $1.8 \pm 0.29$ & $1.7 \pm 0.58$ & n.s. \\
\hline fishy & $1.3 \pm 0.29$ & $1.5 \pm 0.00$ & $2.2 \pm 1.04$ & $1.8 \pm 0.29$ & n.s. \\
\hline muddy & $1.0 \pm 0.00$ & $1.0 \pm 0.00$ & $1.0 \pm 0.00$ & $1.0 \pm 0.00$ & n.s. \\
\hline \multicolumn{6}{|l|}{ Taste: } \\
\hline boiled meat & $2.3 \pm 0.58$ & $2.0 \pm 0.00$ & $2.3 \pm 0.58$ & $2.0 \pm 0.00$ & n.s. \\
\hline fishy & $1.8 \mathrm{a} \pm 0.29$ & $2.7 b \pm 0.00$ & $2.8 \mathrm{~b} \pm 0.58$ & $2.8 b \pm 0.00$ & $* *$ \\
\hline muddy & $1.7 \pm 0.29$ & $1.5 \pm 0.50$ & $1.7 \pm 0.29$ & $1.3 \pm 0.58$ & n.s. \\
\hline
\end{tabular}

${ }^{\mathrm{ab}}$ - values in rows with different index differ significantly ( $\mathrm{p} \leq 0.05$ ).

Significance of influence: n.s. - non significant, ${ }^{*} \mathrm{p} \leq 0.05 ; * * \mathrm{p} \leq 0.01$.

DHA (Aprodu et al., 2012). The most pronounced effect of fish nutrition has been reported to be on total n-3 PUFA contents (1.7-2.5 times), especially EPA and DHA, and the n-3/n-6 ratio, but these effects are dependent on the source of DHA in the feed. In our research, greater amounts of n-3 PUFA, EPA and DHA, and a higher n-3/n-6 ratio were determined in the muscle fat of carp fed diets in which the source of DHA were the algae Schizochytrium sp. (CB1, CB2), and not salmon oil (CB3).

The differences in the EPA and DHA contents observed in fillets were a result of the amounts of these fatty acids in raw materials used for feed production. Oil from Schizochytrium sp. contains $40-45 \%$ of DHA and up to $10 \%$ of EPA (Fedorova-Dahms et al., 2011), whereas the EPA concentrations in salmon oil vary between $4.4 \%$ and $8.8 \%$ of total FAs, and DHA varies from $5.8 \%$ to $7.5 \%$ (Horn et al., 2019). These results contrasted with those by Aprodu et al. (2012), in which more EPA, DHA and HUFA were found in fish fed with fish oil supplements compared with fish fed with vegetables oils. In our study, in the fat from the CB1- and CB2-fed carp, PUFA:SFA $(>0.4)$ and n-6/n-3 $(<4$, or n- 
$3 / \mathrm{n}-6>0.25$ ) ratios were within levels recommended by WHO/FAO.

The effect of nutrition, including the use of feed enriched with PUFAs, on fillet compositions and fatty acid profiles is well recognized in the literature. However, information about the relationship between the amounts of PUFAs in the feed and the parameters of nutritional quality is limited. It is known that fat can have an important role in the visual appearance of fillets, processing yield and taste (Fauconneau et al., 1995). The quality assessment carried out showed significant differences in color brightness ( $\left.\mathrm{L}^{*}, \mathrm{WI}\right)$ and color redness (a*). In contrast, Mazurkiewicz et al. (2011) did not report differences in the color components of fillets from carp fed varying levels of rapeseed oil and meals. In our study, the brightest color was observed in fillets from the control and CB2-fed groups, in which the largest muscle fibers and lowest muscle fat contents were also noted. Conversely, Kiessling et al. (2006) associated the darker color of Atlantic salmon with smaller muscle fibers. The reddest component was observed in fillets from the CB1- and CB3-fed fish, in which crude fat contents were also the highest. The more intense color of fish fed with salmon oil might be due to the presence of astaxanthin from the salmon, which is the typically intense yellow-orange color of carotenoids (Deepika et al., 2014). Adekoya et al. (2018) also showed that the higher content of fish oil contributed to a reduction in $L *$ and $b$ * in carp. Balev et al. (2017) also found that carp fed solely in a natural way had lower $\mathrm{L} *$ and $\mathrm{b}$ * values as well as a greater proportion of red $(\mathrm{a} *)$ compared to carp fed with wheat.

No significant differences in texture and most sensory quality parameters were detected. Literature data show that texture depends on chemical composition and the size of structural elements (Kiessling et al., 2006). Generally, firmness and hardness of cooked fish increase with the number of smaller fibers, fiber density (Johnston et al., 2000; Kiessling et al., 2006), as well as higher amounts of connective tissue (Periago et al., 2005) and insoluble collagen (Moreno et al., 2012) and lower amounts of fat (Saavedra et al., 2017). However, these relationships are not always clear. For the most part, texture and sensory quality is affected by the size of muscle fibers and connective tissue. Mørkøre et al. (2009) showed that the background for salmon fillet texture was multifactorial, and fiber cross-sectional area explained only $10-12 \%$ of the variation in texture properties.

Based on our research, the hardest fillets were those from the CB2 group, the muscle of which were characterized by the largest fibers (CSA, diameter) and the thickest endomysium, and contained little crude fat. The control fillets had the smallest fibers and lowest crude fat content, resulting in the lowest hardness values. Periago et al. (2005) noticed a positive correlation between collagen content and textural parameters, such as hardness, springiness, cohesiveness and chewiness, in sea bass fillets, but muscle fiber diameter was correlated negatively with these parameters. Also, Fauconneau et al. (1995) and Mørkøre et al. (2009) showed that salmon fillets, characterized by small fibers, were firmer than fillets with medium-sized or large muscle fibers. Dong et al. (2017) revealed that hardness and chewiness were linked to higher lipid contents in carp, and it has been suggested that the increasing amounts of lipid enable flesh softening (Fauconneau et al., 1995). The higher contents of unsaturated fatty acids in fillets from fish receiving CB1-CB3 did not significantly affect their sensory evaluation. However, interpretation of sensory assessment data is often very difficult, in cases in which there are no differences in organoleptic criteria, even with large differences in composition (Fauconneau et al., 1995).

Lower moisture was only observed in fillets from the CB3-fed fish, which were also the most susceptible to weight loss caused by freezing and thawing. Yet, no differences were observed between the study groups in weight losses after heat treatment. Mazurkiewicz et al. (2011), initially, also did not find differences in the thermal drip of fillets. However, further studies revealed that lower proportions of rapeseed oil and increased content of meals resulted in a decreased weight loss of fillets after heat treatment.

Fillets from the CB1-fed fish, which had the highest total n-3 PUFAs, including EPA + DHA, were rated as the 'fattiest' fillets, and Fauconneau et al. (1995) associated higher contents of unsaturated fatty acids with fat fluidity that was detectable on consumption. Fillets from carp fed with the CB1-CB3 feeds received higher scores for fishy odor and taste than the control fish. Balev et al. (2017) did not report differences in the sensory properties of color or consistency in grilled fish, but grilled carp fed only in a natural way compared to carp fed with wheat had a significantly more pronounced taste and smell. The more intense fish flavor and aroma might be due to the higher contents of unsaturated fatty acids, which contributes to an increased susceptibility to oxidation (Fauconneau et al., 1995). Lazo et al. (2017) linked the specific seafood flavor with lipid-derived aroma components produced by the enzymatic oxidation of PUFA, especially arachidonic acid, EPA and DHA. According to Fauconneau et al. (1995), lipid oxidation affects specific detectable tastes of fish.

\section{Conclusion}

Feeding carp with feeds enriched with algae and fish fats improved significantly the nutritional value of fillets without compromising quality. Compared with the control fillets, the fillets of fish fed with fortified feeds had lower protein and higher fat contents and better fatty acid profiles, especially the most valuable total n-3 PUFA, EPA and DHA, as well as lighter color, greater redness and low to medium intensity of fishy odor and taste. Yet, none differed in instrumental or sensory texture. At the same time, the use of Schizchytrium sp. meal as a source of EPA and DHA in the feed yielded much better results in terms of EPA and DHA fortification than salmon oil, again without compromising quality and weight losses during thawing, which are associated with economic losses. Therefore, the appropriate supplementation of feed for carp could be an excellent tool for aquaculture, significantly contributing to an improved nutritional value of raw materials without adversely affecting culinary quality.

\section{CRediT authorship contribution statement}

M. Sobczak: Conceptualization, Writing - review \& editing, Investigation, Supervision. R. Panicz: Conceptualization, Writing - review \& editing, Validation. P. Eljasik: Writing - original draft, Investigation, Visualization. J. Sadowski: Resources. A. Tórz: Formal analysis. J. Żochowska-Kujawska: Writing - review \& editing. V. Barbosa: Writing - review \& editing. V. Domingues: Investigation. A. Marques: Writing - review \& editing. J. Dias: Resources.

\section{Declaration of competing interest}

The authors declare that they have no known competing financial interests or personal relationships that could have appeared to influence the work reported in this paper.

\section{Acknowledgements}

This research is part of the EU Horizon2020 project SEAFOOD $^{\text {TOMORROW }}$. This project has received funding from the European Union's Horizon 2020 funding programme, Grant Agreement no. 773400 (SEAFOOD ${ }^{\text {TOMORROW }}$ ). This output reflects the views of the author(s), and the European Commission cannot be held responsible for any use that might be made of the information contained therein.

\section{References}

Adekoya, A., Porcadilla, M., Varga, D., Kucska, B., 2018. Replacing fish meal with alternative protein sources in common carp's feed. Acta Agraria Kaposváriensis 22 (2), $18-24$.

Aprodu, I., Vasile, A., Gurau, G., Ionescu, A., Paltenea, E., 2012. Evaluation of nutritional quality of the common carp (Cyprinus carpio) enriched in fatty acids. Ann. Univ. 
Dunarea de Jos of Galati Fascile VI-Food Technol. 36 (1), 61-73.

AOAC, 2012. Official Methods of Analysis of AOAC International. Red. G.W. Latimer Jr., Gaithersburg (Maryland).

Balev, D.K., Vlahova-Vangelova, D.B., Dragoeva, P.S., Nikolova, N., Dragoev, S.G., 2017. A comparative study on the quality of scaly and mirror carp (Cyprinus carpio L.) cultivated in conventional and organic systems. Turk. J. Fish. Aquat. Sci. 17, 395-403.

Bourne, M.C., 1982. Food Texture and Viscosity: Concept and Measurement. Academic Press, New York, London, pp. 114-118.

Buchtová, H., Svobodová, Z., Křižek, M., Vácha, F., Kocour, M., Velíšek, J., 2007. Fatty acid composition in intramuscular lipids of experimental scaly crossbreds in 3-yearold common carp (Cyprinus carpio L.). Acta Vet. Brno 76, S73-S81.

Burck, H.Ch, 1975. Fixation. In: Histological Techniques. Państwowy Zakład Wydawnictw Lekarskich, Warszawa, pp. 62-63 (in Polish).

Calder, P.C., 2006. $n-3$ polyunsaturated fatty acids, inflammation, and inflammatory diseases. Am. J. Clin. Nutr. 83 (6), 1505S-1519S. https://doi.org/10.1093/ajcn/83. 6.1505S.

Calder, P.C., Yaqoob, P., 2009. Omega-3 polyunsaturated fatty acids and human health outcomes. Biofactors 35 (3), 266-272.

Calder, P.C., Yaqoob, P., 2010. Omega-3 polyunsaturated fatty acids, cardiovascular disease and stability of atherosclerotic plaques. Cell. Mol. Biol. 56 (1), 28-37.

Deepika, D., Vegneshwaran, V.R., Julia, P., Sukhinder, K.C., Sheila, T., Heather, M., Wade, M., 2014. Investigation on oil extraction methods and its influence on omega-3 content from cultured salmon. J. Food Process. Technol. 5, 401. https://doi.org/10. 4172/2157-7110.1000401.

Dong, X.-P., Wu, Q., Li, D.-Y., Wang, T., Pan, J.-F., Zheng, J.-J., Fu, X.-X., Qi, L.-B., Chen, G.-B., 2017. Physiochemical, micro-structural, and textural properties of different parts from farmed common carp (Cyprinus carpio). Int. J. Food Prop. 20 (4), 946-955.

Dymkowska-Malesa, M., Walczak, Z., Zakrzewski, J., 2014. Evaluation of the level of fish consumption among students in grades 4-6 of primary schools in Koszalin. Probl. Hig. Epidemiol. 95 (1), 182-185 (in Polish).

Fauconneau, B., Alami-Durante, H., Laroche, M., Marcel, J., Vallot, D., 1995. Growth and meat quality relations in carp. Aquaculture 129, 265-297.

Fedorova-Dahms, I., Marone, P.A., Bauter, M., Ryan, A.S., 2011. Safety evaluation of DHA-rich algal oil from Schizochytrium sp. Food Chem. Toxicol. 49, 3310-3318.

Grela, E.R., Pisarski, R.D., Kowalczuk-Vasilev, E., Rudnicka, A., 2010. Zawartość składników odżywczych, mineralnych i profil kwasów tłuszczowych w miesie wybranych gatunków ryb w zależności od terminu odłowu. ZYWNOSC Nauka Technol. Jakosc 4 (71), 63-72 (in Polish).

Hadley, K.B., Bauer, J., Milgram, N.W., 2017. The oil-rich alga Schizochytrium sp. as a dietary source of docosahexaenoic acid improves shape discrimination learning associated with visualprocessing in a canine model of senescence. Prostagl. Leukot. Essent. Fat. Acids 118, 10-18.

Horn, S.S., Sonesson, A.K., Krasnov, A., Moghadam, H., Hillestad, B., Meuwissen, T.H.E., Ruyter, B., 2019. Individual differences in EPA and DHA content of Atlantic salmon are associated with gene expression of key metabolic processes. Sci. Rep. 9, 3889. https://doi.org/10.1038/s41598-019-40391-2.

Johnston, I.A., Alderson, R., Sandham, C., Dingwall, A., Mitchell, D., Selkirk, C., Nickell, D., Baker, R., Robertson, B., Whyte, D., Springate, J., 2000. Muscle fibre density in relation to the colour and texture of smoked Atlantic salmon (Salmo salar L.). Aquaculture 189, 335-349.

Kiessling, A., Ruohonen, K., Bjørnevik, M., 2006. Muscle fibre growth and quality in fish.
Arch. Tierz., Dummerstorf 49 (Special issue), 137-146.

Lazo, O., Guerrero, L., Alexi, N., Grigoriakis, K., Claret, A., Pérez, J.A., Bou, R., 2017. Sensory characterization, physico-chemical properties and somatic yields of five emerging fish species. Food Res. Int. 100, 396-406.

Ljubojević, D., Ćirković, M., Novakov, N., Jovanović, R., Janković, S., Dordević, V., Trbović, D., 2012. The impact of diet on meat quality of common carp. Arch. Zootec. 15 (3), 69-78.

Ljubojevic, D., Trbovic, D., Lujic, J., Bjelic-Cabrilo, O., Kostic, D., Novakov, N., Cirkovic, M., 2013. Fatty acid composition of fishes from inland waters. Bulg. J. Agric. Sci. 1, 62-71 Supplement.

Maciel, E.S., Sonati, J.G., Galvão, J.A., Oetterer, M., 2019. Fish consumption and lifestyle: a cross-sectional study. Food Sci. Technol. 39 (Suppl. 1), 141-145.

Manjappa, K., Keshavanath, P., Gangadhara, B., 2002. Growth performance of common carp, Cyprinus carpio fed varying lipid levels through protein diet, with a note on carcass composition and digestive enzyme activity. Acta Ichtiologica et Piscatoria XXXII (2), 145-155.

Mazurkiewicz, J., Przybył, A., Czyżak-Runowska, G., Łyczyński, A., 2011. Cold-pressed rapeseed cake as component of the diet of common carp (Cyprinus carpio L.): effects on growth, nutrient utilization, body composition and meat quality. Aquacult. Nutr. 17, 387-394.

Moreno, H.M., Montero, M.P., Gómez-Guillén, M.C., Fernández-Martín, F., Mørkøre, T., Borderías, J., 2012. Collagen characteristics of farmed Atlantic salmon with firm and soft fillet texture. Food Chem. 134, 678-685.

Mørkøre, T., Ruohonen, K., Kiessling, A., 2009. Variation in the texture of farmed atlantic salmon (Salmo salar L.) relevance of muscle fiber cross-sectional area. J. Texture Stud. $40,1-15$.

Periago, M.J., Ayala, M.D., López-Albors, O., Abdel, I., Martínez, C., García-Alcázar, A., Ros, G., Gil, F., 2005. Muscle cellularity and flesh quality of wild and farmed sea bass, Dicentrarchus labrax L. Aquaculture 249, 175-188.

Pieniak, Z., Verbeke, W., Scholderer, J., 2010. Health-related beliefs and consumer knowledge as determinants of fish consumption. J. Hum. Nutr. Diet. 23 (5), 480-488.

PN-EN ISO 12966-1:2015-01, 2015. Animal and Vegetable Fats and Oils - Gas Chromatography of Fatty Acid Methyl Esters - Part 1: Guidelines on Modern Gas Chromatography of Fatty Acid Methyl Esters.

PN-ISO 11036:1999, 1999. Sensory Analysis - Methodology - Texture Profiling. (in Polish).

Ryan, A.S., Zeller, S.G., Nelson, E.B., 2010. Safety evaluation of single cell oils and the regulatory requirements for use as food ingredients. In: Ratledge, C., Cohen, Z. (Eds.), Single Cell Oils. AOCS Press, pp. 317-350.

Saavedra, M., Pereira, T.G., Carvalho, L.M., Pousão-Ferreira, P., Grade, A., Teixeira, B., Quental-Ferreira, H., Mendes, R., Bandarra, N., Gonçalves, A., 2017. Wild and farmed meagre, Argyrosomus regius: a nutritional, sensory and histological assessment of quality differences. J. Food Compos. Anal. 63, 8-14.

Skibniewska, K.A., Radzymińska, M., Jaworska, M.M., Babicz-Zielińska, E., 2009. Badania zwyczajów żywieniowych studentów polskich i belgijskich. 2009. ZYWNOSC Nauka Technol. Jakosc 4 (65), 250-258 (in Polish).

WHO/FAO, 2003. Diet, nutrition and the prevention of chronic diseases. Report of a Join WHO/FAO Expert Consultation. WHO Tech. Rep. Ser. 916, 90.

Woźniak, M., Poczyczyński, P., Kozłowski, K., 2013. The nutritional value of selected species of fish from lake and fish farm of nort-eastern Poland. Pol. J. Nat. Sci. 28 (2), 295-304. 